ENTREPRENEURSHIP AND SUSTAINABILITY ISSUES

ISSN 2345-0282 (online) http://jssidoi.org/jesi/

2020 Volume 8 Number 1 (September)

http://doi.org/10.9770/jesi.2020.8.1(33)

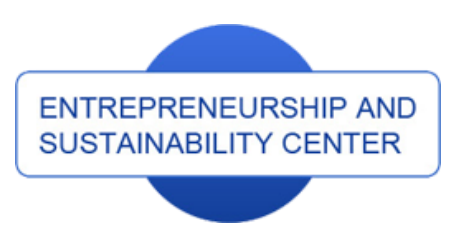

Publisher

http://jssidoi.org/esc/home

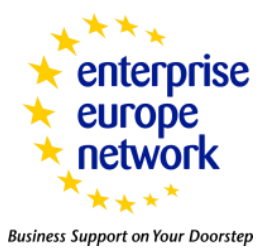

CASPA

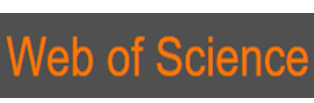

1) Clarivate

\title{
FORMS OF ORGANIZATION AND SPATIAL CONCENTRATION OF LOCAL FOOD SYSTEMS. A CASE FROM POLAND
}

\author{
Ola Bareja-Wawryszuk \\ Institute of Management and Quality Sciences, University of Natural Sciences and Humanities in Siedlce, \\ ul. Żytnia 39, 08-110 Siedlce, Poland \\ E-mail: ola.bareja-wawryszuk@edu.uph.pl
}

Received: 20 February 2020; accepted 20 June 2020; published 30 September 2020

\begin{abstract}
A close analysis of the modern combined agri-food industry shows two prevailing development trends. The first one is the trend towards mass-produced food based on high impact production methods and delivered through long supply chains. The second trend suggests growing popularity of local food. Local food systems constitute an alternative approach to the production and consumption of food and fit in the idea of sustainable development. We may analyze local food systems at various levels, with respect to their environmental action, local communities, and regional economy. The article is an analysis of the forms of organization and spatial concentration of local food systems in Poland. Forms of entities such as: direct sale, agricultural retail sale and, marginal, localized and restricted activities are described. The forms of organization are not only continually changing, but they also vary from country to country, which contributed to the decision to undertake this research. The article presents the spatial diversity of individual local entities both in absolute terms and in relation to selected regional features. The analysis of the spatial structure of direct sales revealed concentration of DS entities in the south-west and central Poland. The regions of large spatial concentration of agricultural retail trade are the WarmińskoMazurskie, Lubelskie, Dolnośląskie and Mazowieckie provinces. The entities in the last studied group, i.e. marginal, localized and restricted entities, are present in great numbers across Mazowsze, Little Poland, and Silesia. The study was conducted based on methods such as review of literature and legal acts, methods of graphic presentation in the form of maps and calculation of the localization coefficient. The presented analysis allowed the researcher to determine the organization and localization of the local market in Poland. The results of the study may become guidelines on regional policy and new business action development.
\end{abstract}

Keywords: local food systems; forms of organization; spatial concentration; marginal, localized and restricted activities; direct sale; agricultural retail trade

Reference to this paper should be made as follows: Bareja-Wawryszuk, O. 2020. Forms of organization and spatial concentration of local food systems. a case from Poland. Entrepreneurship and Sustainability Issues, 8(1), 471-483. http://doi.org/10.9770/jesi.2020.8.1(33)

JEL Classifications: L22, L23, L66, O13, Q01, Q13, D47, F64 


\section{ENTREPRENEURSHIP AND SUSTAINABILITY ISSUES}

ISSN 2345-0282 (online) http://jssidoi.org/jesi/

2020 Volume 8 Number 1 (September)

http://doi.org/10.9770/jesi.2020.8.1(33)

\section{Introduction}

There are several terms which refer to direct relations between food manufacturers and final consumers operating within a limited geographical area (Balazs et al., 2013). Phenomena, such as direct sale, short supply chains, extensive agriculture, traditional methods of processing, or local consumption appear in literature under different names (Fegan, 2007). The most popular phrase which combines the said issues is 'local food systems' (Feenstra, 1997; Gorelick et al., 2007; Henderson, 1998; Lacy, 2000). Feenstra (1997) describes local food systems as the systems identified with production regions, which are committed to the optimization of economic performance of food chain participants, which employ sustainable methods of production and distribution, and which promote direct social relations. At present, the above approach to food systems is the clear trend in food production and consumption in numerous countries (Malak-Rawlikowska et al., 2019; (Michel-Villarreal, 2019). According to the European Committee of the Regions (2011), 80\% of food worldwide is produced and sold locally. In the European Union states, the average percentage is 20. Researches demonstrate that local food systems are highly diversified among the EU states with respect to quantity (from $0.5 \%$ of total food production in Ireland to $34.6 \%$ in Italy) and the form of operation (European Commission, 2013; Biasini, 2018). What is more, there is a large variation in terms of profiles and spatial distribution of local entities.

\section{Methodology}

The main research question of the paper stated: What are the possible forms of organization of local food systems in Poland and how they are spatially concentrated across Poland? Therefore, the research presented in this article was intended, above all, to identify and characterize the forms of organization of local food systems in Poland. The second research objective was to present the spatial distribution of the identified entities. The subject of the analysis were entities committed to the production, processing, and sale of products of animal origin on the local market. The research group does not include entities which produce and sale products of plant origin, what can be regarded as limitations of the research. The study hypotheses were that local food systems adopted organizational (legal) forms that were different from those of business entities in other industries. Furthermore, it was assumed that the analyzed entities were characterized by diverging spatial system across Poland and constituted a large group of entities in relative terms. The study was based on the register of local entities maintained by the General Veterinary Inspectorate (GIW) as of 31 Dec 2017 and secondary data published by the Central Statistical Office (GUS). The identification of the organizational forms of local food systems was conducted under the legal framework governing the combined agri-food sector. The spatial distribution of the analyzed entities was developed with the use of QGIS 3.4.5 'Madeira'. At the subsequent stage of the research, localization coefficients were set, on the basis of which the sizes of individual groups of entities could be confronted with variables specific to individual regions, such as: the percentage of all MLL entities in a region with the number of all entities involved with industrial processing, the percentage of ART and DS entities in a region with the total number of individual farms. The calculations were performed in the MS Excel. Localization coefficients were calculated according to the following rule 1:

$L Q i r==\frac{X_{r i / z_{r i}}}{X_{i / z_{i}}}$

where:

$L Q_{r}{ }^{i}-$ localization coefficient of the analyzed activity in the $i$-th region of Poland, where $i \epsilon$ $\{1, \ldots 16\}$, 


\section{ENTREPRENEURSHIP AND SUSTAINABILITY ISSUES}

ISSN 2345-0282 (online) http://jssidoi.org/jesi/

2020 Volume 8 Number 1 (September)

http://doi.org/10.9770/jesi.2020.8.1(33)

$X_{r i}$ - the number of analyzed entities registered in the $i$-th region,

$Z_{r i}$ - the number of entities constituting a reference point depending on the group of local

entities in the $i$-th region in 2017 ,

$X_{i}$ - the number of all analyzed local entities in Poland in 2017,

$Z_{r i}$ - the number of all entities constituting a reference point depending on the group of local

entities in Poland in 2017,

\section{Identification and characterization of local food system entities in Poland}

Even though the notion 'local food systems' has been used for a long time in the Polish language, there is no single official definition which would account for the nature of the phenomenon. In subject literature, there are various definitions of the term. According to Blouin et al. (2009), local food systems are identified as an effective method in the pursuit of nutritional sovereignty, defined as the right of the society to have access to local, healthy and eco-friendly food manufactured with due respect for every partner in the supply chain and assuraning adequate working conditions and remuneration. There are three common criteria based on which local food systems can be characterized. The geographic criterion assumes that there is a distance between the consumer and the producer. Some sources provide the distance between $20 \mathrm{~km}$ and $100 \mathrm{~km}$ (Balazs et al., 2013) or even $80 \mathrm{~km}$ to over $100 \mathrm{~km}$ (Brown, Miller, 2008). In Poland, the spatial dimension of local food systems frequently becomes tantamount to an administrative area, i.e. one province (in Polish: województwo). The ambiguity of the criterion justifies the use of others. The term 'local food system' is applied whenever the number of entities in the supply chain is minimal (Ilbery, Maye, 2006). This is crucial not only as a marker of quality, authenticity and freshness, but also as a producer's way to generate real financial profit. The final criterion of defining local food systems refers to direct relations between system participants. They favor the establishment of social bonds which improve local community operations and develop a sense of regional affiliation (Devon County Council, 2011). Another approach to local food systems may be found in the definition suggested by the Department for Environment, Food and Rural Affairs UK (2003), which provides that local food systems are produced, processed and sold in a specific geographical area, economically effective for producers, processors and sellers, healthy, fair trade, employees' rights are not abused, production techniques are environmentally friendly, respecting food culture In Poland, local production is subject to legal regulations which set out the detailed conditions of production, processing and local sale, the territorial scope of conducted activities, and production limitations. The activity comprises four forms of organization, i.e.:

- $\quad$ direct sale (DS) - which refers to the sale of products of animal origin;

- direct supply (DSu) - which refers to the sale of products of plant origin;

- agricultural retail trade (ART) - which refers to products of plant and animal origin;

- marginal, localized and restricted enterprises (MLL) - which refer to products of animal origin.

As of 31 December 2017, in Poland there are 12,765 locally focused entities dealing with the production, processing, and sale of products of animal origin, which are the object of research in this project (GIW, 2017). The most populous group are entities operating as part of direct sale.

Direct sale consists of rendering available unprocessed products of animal origin to final recipients, excluding agents, to satisfy their needs. The direct sale opportunity pertains only to those products which are produced from own raw materials, made available within the territory of the province on which the production takes place or in the neighboring areas. In special cases, i.e. during exhibitions, picnics, fairs or markets organized with a view to promote local products, sale on the territory of other provinces is allowed (Regulation of the Minister of Agriculture and Rural Development of 30 September 2015, 2015). Direct sale covers the sale of poultry, lagomorphs, game, fishery products, live snails, milk and sour cream, eggs for consumption, and unprocessed 


\section{ENTREPRENEURSHIP AND SUSTAINABILITY ISSUES}

ISSN 2345-0282 (online) http://jssidoi.org/jesi/

2020 Volume 8 Number 1 (September)

http://doi.org/10.9770/jesi.2020.8.1(33)

apiculture products (General Veterinary Inspectorate, 2017a). The volumes of production and sales of the above listed items is strictly determined and cannot exceed statutory limitations. The channels of distribution of the products of direct sale comprise:

- places where the production of the products held for direct sale takes place, including farms, apiaries, or fish farms;

- open-air markets;

- mobile equipment and objects, or temporary means of transport located within production areas, within openair markets, or externally.

- retail trade establishments targeting the final consumer.

In addition, in the case of milk, the sale of products from distribution equipment designed to sell foods is permitted. Direct selling to the final consumer may also take place electronically, by shipment, and via the system of direct delivery to the consumer, as part of the so-called cooperatives. The place of production of products for direct sale should be in buildings which are detached from housing units or in adjusted rooms. All objects and equipment used for production as part of direct sale must meet sanitation requirements and guarantee safety of the production process. The most restrictive veterinary requirements refer to those places where carcasses, giblets, offal of lagomorphs or game and fishery products are handled for bleeding, heading, removal of fins and gutting. The absence of the need to implement the complete HACCP system and less frequent checks on the part of the General Veterinary Inspectorate are convenient for direct sale entities. The entities involved in direct sale are obliged to establish documents confirming the quantity of sold products, covering the results of water checks and medical certificates on the ability to performs works related to food production. All products sold as part of direct sales ought to be properly marked and labelled, which makes them identifiable and traceable. The body in charge of registration and supervision of direct sales is the Veterinary Inspectorate.

Detailed guidelines setting out the conditions of conducting direct sale are included in the Regulation of the Minister of Agriculture and Rural Development of 30 September 2015 on veterinary requirements applied to the production of products of animal origin due for direct sale.

The newest group of entities within the local food systems are the entities conducting the so-called agricultural retail trade (ART). The provisions facilitating farmers' processing and sale of agricultural and food products entered into force on 1 January 2017. Under the law (Regulation of the Minister of Agriculture and Rural Development of 16 Dec 2016, 2016), farmers may sell processed agricultural products produced on their own farms only after they had registered their activity as agricultural retail trade, without validation. This signifies that farmers may produce and sell the following: hams, sausages, pates, butter, milk, eggs, cheese, pickles, silage, nonmeat based convenience foods, pies (pierogi) filled with meat, flour, porridge, flakes, bran, bread, confectionery, oils, juices, jams etc. Ipso facto, as part of agricultural retail trade one is able to produce, process and sell agrifood products intended for the final consumer and, as of 1 January 2019, for the purpose of retail trade establishments providing supplies to final consumers, such as restaurants, schools, canteens, and other institutions within a given territory. The production and sale of food as part of ART may not involve agents. Agricultural retail trade comprises products of both animal and plant origin, including undergrowth. The area of activity of agricultural retail trade is limited, similarly as in the case of direct sale, to the area of the province where the food is produced, and to the poviat or the city which is the seat of the Governor of a given province or of the Regional Council of the province adjacent to the province of product origin. The underlying condition of carrying out agricultural retail trade is possessing own raw materials to produce food. Agri-food products provided to final consumers as part of ART in whole or in part must originate from one's own farming, except for water. Moreover, processing and sale ought to be conducted according to the statutory quantitative and qualitative limits. The processing and sale of products of animal and plant origin may not be performed with the participation of people employed under the contract of employment, contract of mandate or task-specific contract, with certain exceptions. Furthermore, any agricultural retail entity shall have a duty to keep a register of food sales. The sale as part of ART, as is already the case for direct sale, is allowed: 


\section{ENTREPRENEURSHIP AND SUSTAINABILITY ISSUES}

ISSN 2345-0282 (online) http://jssidoi.org/jesi/

2020 Volume 8 Number 1 (September)

http://doi.org/10.9770/jesi.2020.8.1(33)

- at the place of production;

- at places intended for retail trade, such as open-air markets;

- at establishments conducting retail trade intended for the final consumer;

- from mobile equipment and objects, or temporary means of transport located within production areas, within open-air markets, or externally.

Moreover, activities conducted as part of agricultural farming also cover online sale of processed agricultural products and shipment to the final consumer. In the event of ART entities, there is no obligation to develop a technological project of the production area. It is possible to hold production inside private homes and with the use of household appliances. What is more, there is no need to introduce a complete HACCP system. Nonetheless, one must follow the principles of the so-called good production practice and good hygiene practice. All agricultural retail trade products should be identifiable and properly marked, allowing full traceability of products throughout the supply chain. It is crucial to place the "Polish product" label on the ART-manufactured products (Minister of Agriculture and Rural Development, 2019a). The registrar and supervisor of agricultural retail trade entities is the General Veterinary Inspectorate. At the turn of the year 2018 and 2019, the tax provisions regarding agricultural retail trade were amended. An increased tax relief amount was introduced, which means that any income up to PLN 40,000 per annum generated as part of ART is exempt from tax. Before January 2019, the amount exempt from tax was PLN 20,000.

Another possible form of activity as part of local food systems is to run marginal, localized and restricted activities (MLL). MLL activity registration in Poland has been available since 2007. The scope of activities of the MLL companies covers the production and sale of processed and unprocessed products of animal origin to the final consumer and shipping produced foods to retail trade establishments intended for the final consumer (Regulation of the Minister of Agriculture and Rural Development of 30 September 2015, 2015).

Marginal, localized and restricted activity provides an opportunity to conduct production, processing and sale to small business entities and family production establishments, which offer products of specific, unique features. MLL are identified with the strategy of local production support by allowing activities of reduced technical, organizational and tax requirements (Bareja-Wawryszuk et al.,2019). The territorial scope of MLL activities is also limited to the area of one province or the area of poviats adjoining the said province but located in other provinces. As part of marginal, localized and restricted activities, business related to the production and sale of the following products of animal origin may be conducted:

- cutting of fresh bovine meat, pig meat, sheep meat, goatmeat, horsemeat, poultry meat or lagomorph meat, or

- cutting of fresh meat of game culled in accordance with the provisions of the hunting law, or

- cutting of meat of wild animals kept at farms, or

- production of mincemeat, raw meat preparations, or

- production of meat products, or

- production of initially processed or processes fishery products, or

- production of dairy products or colostrum-based products made of milk or colostrum, Dproduction of egg products acquired as a result of the handling or processing of eggs previously boiled in shells,

- production of prepared food (meals) made of products of animal origin.

In addition, the cutting and sale of fresh bovine meat, pig meat, sheep meat, goatmeat, horsemeat, poultry meat or lagomorph meat, game meat or meat of wild animals kept on farms is also possible (Regulation of the Minister of Agriculture and Rural Development of 21 March 2016, 2016). The production limitations on the above products were revised on 1 January 2019. As part of promoting local activity, maximum volumes of production of the products intended for the final consumer have been lifted. This signifies that in the case of the sale of products to 
the final consumer, only the area of conducting sales, not quantity, as hitherto, is reduced. The processing and sale of products produced as part of marginal, localized and restricted activity may be performed in special buildings designed for production, in adjusted rooms (such as an outdoor kitchen) or in the rooms of residential units where food is prepared. The equipment in such rooms should conform to the requirements specified in the Regulation (EC) No. 852/2004. Furthermore, any establishment should develop HACCP rules and follow the principles of good practice. Products offered as part of MLL should meet microbiological criteria, storage temperature and cold chain requirements. The registrar and supervisor of MLL companies is, as in the case of other entities processing products of animal origin, the General Veterinary Inspectorate. The distribution channels of the above listed products are the same as the distribution channels in the case of direct sale and agricultural retail trade.

\section{Identification and characterization of local food system entities in Poland}

The entities dealing with direct sale constitute the most populous group of the object of the research. By the end of 2017, there were 9,340 entities registered in Poland. Direct sale in spatial terms is presented in Figure 1.

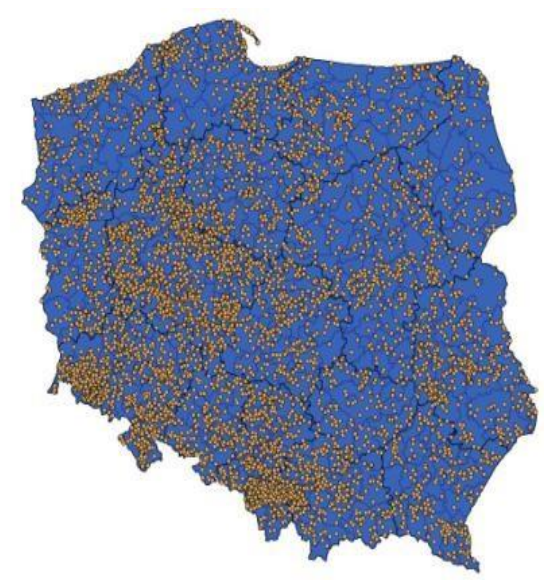

Figure 1. Distribution of direct sale entities in 2017

Source: GIW, 2017a. Own research.

The most direct selling entities in absolute terms operate in the following provinces: Wielkopolskie (kaliski, gnieźnieński poviats), Dolnośląskie (kłodzki, jeleniogórski poviats) and Śląskie (bielski, pszczyńśki poviats). Across the three provinces we have $42.3 \%$ of all direct sale entities. On the contrary, the provinces with the lowest number of direct sale entities are: Opolskie (brzeski, namysłowski poviats, Opole city), Podlaskie (Białystok city, bielski poviat), Świętokrzyskie (sandomierski poviat, Starachowice city).

With a view to present the distribution of direct sale, the coefficients of localization for each province were calculated. The number of direct sale entities in individual provinces was confronted with the number of all individual farms conducting agricultural activities in 2016. Direct sale is conducted in all 16 Polish provinces (in 373 poviats in Poland). The mean direct sale localization coefficient was 1.48. An above average localization coefficient was generated by 8 provinces. Table 1 shows the values of localization coefficients for each province. 
Table 1. Province ranking by localization coefficient for direct sale in 2017

\begin{tabular}{|c|c|c|c|c|}
\hline Item & Province & $\begin{array}{c}\text { No. of } \\
\text { DS }\end{array}$ & $\begin{array}{c}\text { No. of } \\
\text { individual } \\
\text { farms in 2016 }\end{array}$ & $\begin{array}{c}\text { Localization } \\
\text { coefficient }\end{array}$ \\
\hline $\mathbf{1}$ & Lubuskie & $\mathbf{4 9 8}$ & $\mathbf{2 0 ~ 0 1 2}$ & $\mathbf{3 . 7 5}$ \\
\hline $\mathbf{2}$ & Dolnośląskie & $\mathbf{1 2 7 2}$ & $\mathbf{5 5 5 5 3}$ & $\mathbf{3 . 4 5}$ \\
\hline $\mathbf{3}$ & Zachodniopomorskie & $\mathbf{5 5 7}$ & $\mathbf{2 9 1 9 8}$ & $\mathbf{2 . 8 7}$ \\
\hline $\mathbf{4}$ & Wielkopolskie & $\mathbf{1 9 2 2}$ & $\mathbf{1 2 0 5 8 4}$ & $\mathbf{2 . 4 0}$ \\
\hline $\mathbf{5}$ & Śląskie & $\mathbf{7 6 4}$ & $\mathbf{5 4 3 6 1}$ & $\mathbf{2 . 1 2}$ \\
\hline $\mathbf{6}$ & Warmińsko-mazurskie & $\mathbf{5 2 6}$ & $\mathbf{4 2 ~ 8 6 2}$ & $\mathbf{1 . 8 5}$ \\
\hline $\mathbf{7}$ & Pomorskie & $\mathbf{4 3 1}$ & $\mathbf{3 8 7 7 7}$ & $\mathbf{1 . 6 7}$ \\
\hline $\mathbf{8}$ & Opolskie & $\mathbf{2 9 0}$ & $\mathbf{2 6} \mathbf{6 8 2}$ & $\mathbf{1 . 6 4}$ \\
\hline 9 & Kujawsko-pomorskie & 428 & 63523 & 1.01 \\
\hline 10 & Małopolskie & 521 & 139765 & 0.56 \\
\hline 11 & Lódzkie & 398 & 123898 & 0.48 \\
\hline 12 & Lubelskie & 531 & 179801 & 0.44 \\
\hline 13 & Mazowieckie & 536 & 212602 & 0.38 \\
\hline 14 & Podlaskie & 311 & 132631 & 0.35 \\
\hline 15 & Podkarpackie & 185 & 81083 & 0.34 \\
\hline 16 & Świętokrzyskie & 170 & 85243 & 0.30 \\
\hline & TOTAL & $\mathbf{9 3 4 0}$ & $\mathbf{1 4 0 6 5 7 5}$ & Mean 1.48 \\
\hline
\end{tabular}

Source: GIW, 2017a. GUS, 2017. Own research.

An above-average value of Localization Coefficient means that in such provinces the number of direct sale entities against the number of individual farms is greater than in the remaining provinces. The provinces with the largest share of direct sale compared to the number of individual farms are: Lubuskie, Dolnośląskie and Zachodniopomorskie provinces. In the case of the Dolnośląskie and Zachodniopomorskie provinces, the result is consistent with the absolute ranking of the regions in terms of the volume of direct sale. In contrast, the lowest level of the value of localization coefficient was found in the Podkarpackie, Podlaskie, and Świętokrzyskie provinces, which is consistent with the low absolute number of entities in the region.

Another group of entities under investigation were entities dealing with agricultural retail trade in products of animal origin. Agricultural retail trade is a form of sale which had been called for over many years in order to have more freedom in the processing and resale of agricultural products. Registration as part of ART began in January 2016 and since then there has been a dynamic growth in the number of ART entities. By December 2017, 1,268 ART-oriented entities had been created in Poland. Between January and December 2018, their number grew by 53\% (General Veterinary Inspectorate, 2018c). The distribution of the entities of agricultural retail trade is shown in Figure 2. 


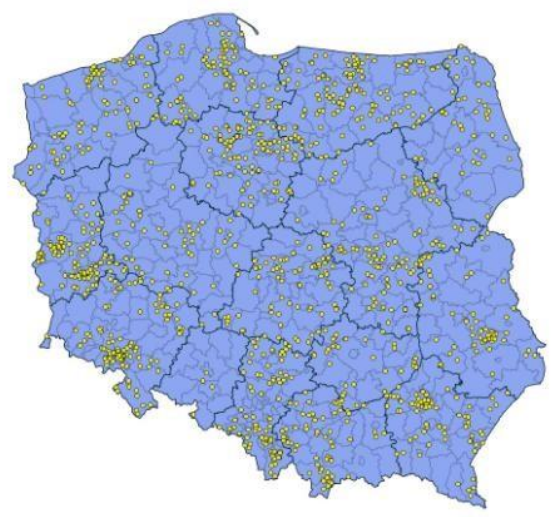

Figure 2. Entities dealing with agricultural retail trade in 2017 Source: GIW, 2017c. Own research

The most entities are registered in the following provinces: Warmińsko-Mazurskie (olsztyński, bartoszycki poviats), Lubelskie (krośnieński, nowosolski poviats) and Dolnośląskie (świdnicki, wałbrzyski poviats). Across the above three provinces, $28.2 \%$ of all ART entities are located. To demonstrate the number of agricultural retail trade entities in relative terms, their spatial diversity was compared with the spatial diversity of individual farms in 2016. The mean value of the coefficient of localization in 16 provinces was 1.64 . In 7 provinces, an aboveaverage occurrence of agricultural retail trade was observed. Table 2 shows province ranking in terms of the value of the coefficient of localization.

Table 2. Province ranking by localization coefficient for agricultural retail trade in 2017

\begin{tabular}{|c|c|c|c|c|}
\hline Item & Province & $\begin{array}{c}\text { Number } \\
\text { ART }\end{array}$ & $\begin{array}{c}\text { No. of } \\
\text { individual } \\
\text { farms in 2016 }\end{array}$ & $\begin{array}{c}\text { Localization } \\
\text { coefficient }\end{array}$ \\
\hline $\mathbf{1}$ & Lubuskie & $\mathbf{1 1 7}$ & $\mathbf{2 0 ~ 0 1 2}$ & $\mathbf{6 . 4 9}$ \\
\hline $\mathbf{2}$ & Zachodniopomorskie & $\mathbf{1 0 1}$ & $\mathbf{2 9 ~ 1 9 8}$ & $\mathbf{3 . 8 4}$ \\
\hline $\mathbf{3}$ & Warmińskomazurskie & $\mathbf{1 2 8}$ & $\mathbf{4 2 ~ 8 6 2}$ & $\mathbf{3 . 3 1}$ \\
\hline $\mathbf{4}$ & Pomorskie & $\mathbf{8 1}$ & $\mathbf{3 8 7 7 7}$ & $\mathbf{2 . 3 2}$ \\
\hline $\mathbf{5}$ & Dolnośląskie & $\mathbf{1 1 3}$ & $\mathbf{5 5 5 5 3}$ & $\mathbf{2 . 2 6}$ \\
\hline $\mathbf{6}$ & Kujawskopomorskie & $\mathbf{9 8}$ & $\mathbf{6 3 5 2 3}$ & $\mathbf{1 . 7 1}$ \\
\hline $\mathbf{7}$ & Śląskie & $\mathbf{8 1}$ & $\mathbf{5 4 3 6 1}$ & $\mathbf{1 . 6 5}$ \\
\hline 8 & Podkarpackie & 77 & 132631 & 0.64 \\
\hline 9 & Lódzkie & 70 & 123898 & 0.63 \\
\hline 10 & Małopolskie & 76 & 139765 & 0.60 \\
\hline 11 & Mazowieckie & 110 & 212602 & 0.57 \\
\hline 12 & Podlaskie & 40 & 81083 & 0.55 \\
\hline 13 & Wielkopolskie & 57 & 120584 & 0.52 \\
\hline 14 & Świętokrzyskie & 37 & 85243 & 0.48 \\
\hline 15 & Lubelskie & 76 & 179801 & 0.47 \\
\hline 16 & Opolskie & 6 & 26682 & 0.25 \\
\hline & Total & $\mathbf{1 2 6 8}$ & $\mathbf{1 4 0 6 5 7 5}$ & Mean: 1.64 \\
\hline & & & & \\
\hline
\end{tabular}




\section{ENTREPRENEURSHIP AND SUSTAINABILITY ISSUES}

ISSN 2345-0282 (online) http://jssidoi.org/jesi/ 2020 Volume 8 Number 1 (September) http://doi.org/10.9770/jesi.2020.8.1(33)

Coefficients of localization above the average value were observed in the following provinces: Lubuskie, Zachodniopomorskie, Warmińśko-Mazurskie, Pomorskie, Dolnośląskie, Kujawskie and Śląskie. This signifies that in the above-mentioned provinces, agricultural retail trade shows a relatively large share with respect to all entities conducting agricultural activities in the area. In turn, relatively low values of the coefficient of localization are seen in Podkarpackie, Łódzkie, Małopolskie, Mazowieckie, Podlaskie, Wielkopolskie, Świętokrzyskie, Lubelskie and Opolskie provinces. Thus, in most regions in Poland, agricultural retail trade against the total of individual farms is below average.

The last group of entities consists in marginal, localized and restricted activities (MLL). Unlike the two above described groups of entities, individuals involved in marginal, localized and restricted activities have an opportunity to choose the method of social insurance, i.e. they may conduct processing and business activities while they continue to be farmers insured at KRUS, or they may have an entrepreneur status and conduct business activities when insured at ZUS. In December 2017, there were 2,157 MLL entities registered in Poland. The distribution of MLL companies is presented in Figure 3.

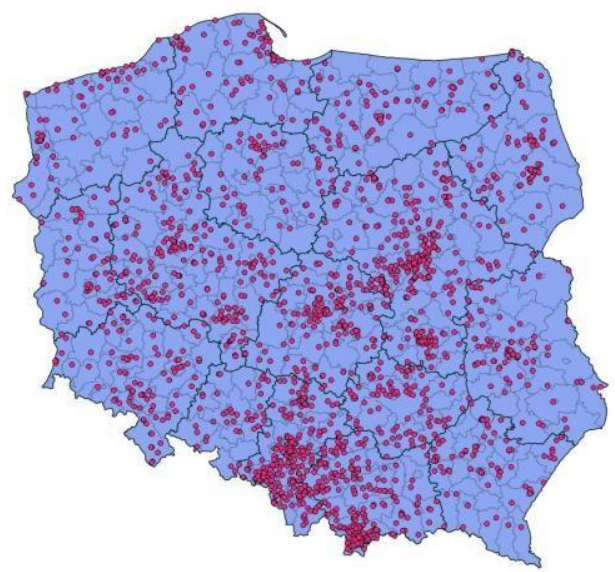

Figure 3. Entities involved in marginal, localized and restricted activities in 2017

Source: GIW, 2017b. Own research.

The largest number of MLL enterprises is detected in the following provinces: Mazowieckie (żyrardowski, radomski poviats), Małopolskie (nowotarski, tatrzański poviats), and Śląskie (cieszyński and wodzisławski poviats). Forty percent of all MLL entities in Poland are located across the above three provinces. In contrast, provinces with the lowest number of MLL entities are: Lubuskie (żarski, sulęciński poviats), Kujawskopomorskie (bydgoski, radziejowski poviats) and Opolskie (prudnicki, namysłowski poviats).

Marginal, localized and restricted activity is one of the legal forms which - according to the PKD code classification - is included in Section C (industrial processing), subsection 10 (food industry). In order to present the size of the group of entities in relative terms, the number of MLL was compared with the total number of the national economy entities (except for natural persons running individual farms) found in the REGON register and dealing with industrial processing, i.e. entities in Section C. The mean value of the coefficient of localization of MLL activities was 1.05. The above average occurrence of marginal, localized and restricted enterprises was observed in the following provinces: Warmińsko-Mazurskie, Świętokrzyskie, Lubelskie. In turn, relatively least MLL companies were noted in Kujawsko-Pomorskie, Pomorskie and Zachodniopomorskie provinces (Table 3). 
Table 3. Ranking of provinces by localization coefficient for marginal, localized and restricted activities in 2017

\begin{tabular}{|c|c|c|c|c|}
\hline Item & Province & $\begin{array}{l}\text { Number } \\
\text { MLL }\end{array}$ & $\begin{array}{c}\text { National } \\
\text { economy } \\
\text { entities } \\
\text { by } \\
\text { Section } \\
\text { (PKD) }\end{array}$ & $\begin{array}{c}\text { Localization } \\
\text { coefficient }\end{array}$ \\
\hline 1 & Warmińskomazurskie & 92 & 10290 & 1.62 \\
\hline 2 & Świętokrzyskie & 89 & 10527 & 1.53 \\
\hline 3 & Lubelskie & 105 & 14028 & 1.35 \\
\hline 4 & Małopolskie & 273 & 36536 & 1.35 \\
\hline 5 & Lubuskie & 65 & 8744 & 1.34 \\
\hline 6 & Śląskie & 262 & 44779 & 1.06 \\
\hline 7 & Podlaskie & 96 & 16589 & 1.05 \\
\hline 8 & Wielkopolskie & 225 & 40036 & 1.02 \\
\hline 9 & Łódzkie & 157 & 28390 & 1.00 \\
\hline 10 & Mazowieckie & 331 & 60365 & 0.99 \\
\hline 11 & Podkarpackie & 84 & 16589 & 0.92 \\
\hline 12 & Opolskie & 44 & 9079 & 0.88 \\
\hline 13 & \begin{tabular}{|l|} 
Dolnośląskie \\
\end{tabular} & 99 & 27353 & 0.65 \\
\hline 14 & Kujawskopomorskie & 63 & 17746 & 0.64 \\
\hline 15 & Pomorskie & 89 & 30823 & 0.52 \\
\hline 16 & Zachodniopomorskie & 83 & 18172 & 0.83 \\
\hline & Total & 2157 & 390046 & Mean: 1.05 \\
\hline
\end{tabular}

Source: GIW, 2017b; GUS, 2017. Own research.

The analysis of the coefficients of localization in individual provinces demonstrates clear disproportions between the absolute number of MLL entities and the relative relation of the number of MLL to national economy entities in Section C. Provinces, where the number of MLL entities in absolute terms was highest, perform below average in the ranking by the value of the coefficient of localization, e.g. Mazowieckie province. This may be due to the size of the province and abundance of entities, which is a reference point for calculating the localization coefficient.

\section{Conclusions}

The study was based on the need to investigate the current trend in agribusiness. i.e. local food systems. The surging popularity of local food systems is equated to the crisis of confidence in the mass combined agrifood industry. The reasons for the crisis are, amongst other things, the spread of pandemics, such as swine fever, bird flu, BSE, ASF, and the fear of genetic modification and food preservatives. In addition, social awareness regarding the natural environment and commitment to environmental sustainability is growing, which contradicts the industrial approach to the agribusiness sector (Blouin et al., 2009). The driving force behind the development of local food systems are both the consumers, looking for valuable foodstuffs, and agricultural producers, seeking alternative forms of business activity. Furthermore, local food systems are of interest to the European policy, as reflected by the Common Agricultural Policy of the EU. The contemporary idea of local food systems as an alternative approach to conventional farming and food processing originated in the seventies in Japan under the name teikei, which means "cooperation, partnership" (Blouin et al., 2009). However, even though the local food system phenomenon has a global reach, it is diversified in terms of the methods of organization. Another fact supporting the research herein is that local food systems are crucial from the point of view of the economy of the region, social ties, and their relevance for the natural environment (Bareja-Wawryszuk, Gołębiewski, 2014). Ipso facto, the author saw the need to analyze the structure of local food systems not only in terms of organization, but also space. The analysis of the entities of the local market in the combined agri-food sector in Poland revealed that 


\section{ENTREPRENEURSHIP AND SUSTAINABILITY ISSUES}

ISSN 2345-0282 (online) http://jssidoi.org/jesi/ 2020 Volume 8 Number 1 (September) http://doi.org/10.9770/jesi.2020.8.1(33)

it features unique organizational structures and legal forms. Entities registered under the name direct sale, agricultural retail trade, or marginal, localized and restricted activity are a separate group of entities authorized to conduct localized activities. The principles of operation of the above entities are simplified with respect to the registration of approved business activities, but they are also limited as far as the scope of activity and turnover are concerned. Fewer legal restrictions and phytosanitary requirements make this type of activity more accessible. The idea of local entities is to promote traditional production and regional development, and to generate alternative business activities. How important local establishments are is emphasized by ongoing legal changes consequential to social postulates appealing for greater freedoms and scopes of local activities. Another vital point is that the number of entities analyzed in the article continues to grow. The visualization of the distribution of each of the studied forms of activity illustrated how numerous a group of entities is direct sale, agricultural retail trade, and marginal, localized and restricted activity. Large numbers of entities described herein operate both in the absolute system and relative to various features of the region, which confirms the need to undertake research in the spatial context. The research results described above indicated that the most numerous group of entities are direct sales entities, i.e. 9.340 entities registered till 31.12.2017 in Poland. The most direct selling entities in absolute terms operate in the following provinces: Wielkopolskie, Dolnośląskie and Śląskie. Across the three provinces we have $42.3 \%$ of all direct sale entities. Provinces with the largest share of direct sale compared to the number of individual farms are: Lubuskie, Dolnośląskie and Zachodniopomorskie provinces. Another analyzed group of entities were agricultural retail trade counting 1,268 ART-oriented entities. However it is a group of entities showing the greatest growth dynamics. The most entities are registered in the following provinces: Warmińsko-Mazurskie, Lubelskie and Dolnośląskie. Across the above three provinces, 28.2\% of all ART entities are located. Coefficients of localization above the average value were observed in the following provinces: Lubuskie, Zachodniopomorskie, Warmińśko-Mazurskie, Pomorskie, Dolnośląskie, Kujawskie and Śląskie. The last group of analized local entities were marginal, localized and restricted activity and by the end of 2017 there were 2,157 MLL entities registered in Poland. The largest number of MLL enterprises is detected in the following provinces: Mazowieckie, Małopolskie, Śląskie. Forty percent of all MLL entities in Poland are located across the above three provinces. The above average occurrence of marginal, localized and restricted enterprises was observed in the following provinces: Warmińsko-Mazurskie, Świętokrzyskie, Lubelskie.

Such a spatial structure of local food systems may be the result of multiple factors, such as: access to raw materials, market, or regional traditions. Information acquired in the course of the research may be used to explain the mechanisms of entity location and can show directions of development for individual regions. The considerations presented in the above article are pioneering and constitute a significant contribution to the knowledge of local food systems in Poland.

\section{References:}

Balázs, B., Blackett, M., Bos, E., Eyden-Wood, T., Gomez Y Paloma, S., Kneafsey, M., ... Trenchard, L. (2013). Short food supply chains and local food systems in the EU. A state of play of their socio-economic characteristics. European Union: Publications Office of the European Union. https://doi.org/10.2791/88784

Biasini, B., Csillag, P., Duboys de Labarre, M., Laitala, K., Lecoeur, J-L., Maj, E. Majewski, A., Malak-Rawlikowska, A., Menozzi, D., Tocco, B., Torjusen, H., Török, A., Vittersø, G., Wavresky, P. (2018). Short Food Supply Chains and Their Contributions to Sustainability: Participants' Views and Perceptions from 12 European Cases. Sustainability 11,4800; https://doi.org/10.3390/su11174800

Blouin, C., Lemay, J.-F., Ashraf, K., Imai, J., Konforti, J. (2009). Local food systems and public policy: a review of the literature. Equiterre and The Centre for Trade Policy and Law, Carleton University. https://pdfs.semanticscholar.org/e638/e79829a1381e71917e06d326b6399352fb64.pdf 


\section{ENTREPRENEURSHIP AND SUSTAINABILITY ISSUES}

ISSN 2345-0282 (online) http://jssidoi.org/jesi/ 2020 Volume 8 Number 1 (September) http://doi.org/10.9770/jesi.2020.8.1(33)

Brown, C., Miller, S. (2008). The impacts of local markets: A review of research on farmers markets and community supported agriculture (CSA). American Journal of Agricultural Economics, 90, 1296-1302. https://doi.org/10.1111/j.1467-8276.2008.01220.x

Bareja-Wawryszuk, O., Drejerska, N., Gołębiewski, J. (2019). Marginal, localized and restricted activity, business models for creation a value of local food products. A case from Poland. British Food Journal. https://doi.org/10.1108/BFJ-05-2018-0337

Bareja-Wawryszuk, O., Gołębiewski, J. (2014b). Economical, environmental and social significance of local food systems. Review of Agricultural and Applied Economics, 17, 2, 74-77. http://dx.doi.org/10.1111/i

Department for Environment, Food and Rural Affairs UK. (2003). Local food - a snapshot of the sector. Downloaded from: http://www.tourisminsights.info/ONLINEPUB/FARMING\%20AND\%20FOOD/FOOD\%20PDFS/LOCAL\%20FOOD.pdf

Devon County Council. (2011). A Local Authority Survey: Buying food with geographical descriptions, How "local” is "local”?. United Kingdom.

Feenstra, G. (1997). Local food systems and sustainable communities. American Journal of Alternative Agriculture, 12, 1, 2336. https://doi.org/10.1017/S0889189300007165

Fegan, R. (2007). The place of food: mapping out the 'local' in local food systems. Progress in Human Geography, 31, 1, $23-42$. https://doi.org/10.1177/0309132507073527

General Veterinary Inspectorate. (2017a). List of entities qualified for direct sale. Downloaded from https://pasze.wetgiw.gov.pl/spi/demosb/index.php

General Veterinary Inspectorate. 2018 List of entities conducting marginal, localized and restricted activities. Downloaded from https://pasze.wetgiw.gov.pl/spi/demorej/index.php?rodzaj=4\&lng=0

General Veterinary Inspectorate. (2017c). List of entities conducting agricultural retail trade. Downloaded from https://pasze.wetgiw.gov.pl/spi/demo/index.php

Central Statistical Office. (2017). Monthly information on the national economy entities in the REGON register, January 2017. Warszawa. Download from: https://stat.gov.pl/obszary-tematyczne/podmioty-gospodarcze-wyniki-finansowe/zmiany-strukturalne-gruppodmiotow/miesieczna-informacja-o-podmiotach-gospodarki-narodowej-w-rejestrze-regon-styczen-grudzien-2017,4,6.html

Gorelick, S., Merrifield, T., Norberg-Hodge, H. (2007). Lokalna żywność, Lokalne alternatywy dla globalnych korporacji rolnych. (Local food, Local alternatives for global agricultural corporations) Kraków: Wydawnictwo Zielone Brygady. Download from: http://www.sopockainicjatywa.org/earth/local-food/Lokalna-zywnosc.pdf

Henderson, E. (1998). Rebuilding local food systems from the grassroots up. An Independent Socialist Magazine, 50, 112-124. https://doi.org/10.14452/MR-050-03-1998-07_9

Ilbery, B., Maye, D. (2006). Retailing local food in the Scottish-English borders: A supply chain perspective. Geoforum, 37, 3, 352-367. https://doi.org/10.1016/j.geoforum.2005.09.003

European Commission Report from the Commission to the Council and the European Parliament on the labelling in local agriculture and direct sale. Brussels. Download from: https://ec.europa.eu/agriculture/sites/agriculture/files/quality/local-farming-directsales/pdf/com-report-12-2013_en.pdf

Committee of the Regions. (2011). Outlook opinion of the Committee of the Regions "Local food systems" Official Journal of the European Union, C 104/1-C 104/6. Download from: https://eurlex.europa.eu/LexUriServ/LexUriServ.do?uri=OJ:C:2011:104:0001:0006:EN:PDF 


\section{ENTREPRENEURSHIP AND SUSTAINABILITY ISSUES}

ISSN 2345-0282 (online) http://jssidoi.org/jesi/ 2020 Volume 8 Number 1 (September) http://doi.org/10.9770/jesi.2020.8.1(33)

Lacy, W. (2000). Empowering communities through public work, science, and local food systems: revisiting democracy and globalization. Rural Sociology, 65, 3-26. https://doi.org/10.1111/j.1549-0831.2000.tb00340.x

Malak Rawlikowska, A., Majewski, E., Was, A., Borgen, S. O., Csillag, P. Donati, M, Freeman, R., Hoang, V., Lecoeur, J.-L., Mancini, M., Nguyen, A., Monia, S., Tocco, B., Török, Á., Veneziani, M., Vittersø, G., Wavresky, P., (2019). Measuring the Economic, Environmental, and Social Sustainability of Short Food Supply Chains. Sustainability. 11(15)4004. https://doi.org/10.3390/su11154004

Michel-Villarreal, R., Vilalta-Perdomo, E., Hingley, M., (2019). Towards an understanding of farmers' motivations and challenges within Short Food Supply Chains: The case of farmers' markets in Mexico. Conference Paper available at: https://www.researchgate.net/publication/330856949_Towards_an_understanding_of_farmers'_motivations_and_challenges_with in_Short_Food_Supply_Chains_The_case_of_farmers'_markets_in_Mexico

Ministry of Agriculture and Rural Development. 2018 Rolniczy handel detaliczny - informacje podstawowe. (Agricultural retail trade basic information) Downloaded from https://www.gov.pl/web/rolnictwo/rolniczy-handel-detaliczny-informacje-podstawowe

Ministry of Agriculture and Rural Development. (2019b). Veterinary requirements for the production and sale of products of animal origin as part of marginal, localized and restricted activities. Downloaded from https://www.gov.pl/web/rolnictwo/wymaganiaweterynaryjne-dla-prowadzenia-produkcji-i-sprzedazy-produktow-pochodzenia-zwierzecego-w-ramach-dzialalnoscimarginalnej-lokalnej-i-ograniczonej

Regulation of the Minister of Agriculture and Rural Development of 16 December 2016 on the maximum amount of food sold as part of agricultural retail trade and the scope and method of its recording, J. of Laws 2016, Item 2159.

Regulation of the Minister of Agriculture and Rural Development of 21 March 2016 on the detailed conditions of authorizing marginal, localized and restricted activity, J. of Laws 2016, Item 451.

Regulation of the Minister of Agriculture and Rural Development of 30 September 2015 on veterinary requirements applied to the production of products of animal origin due for direct sale, J. of Laws Item 1703.

Regulation (Eu) No 1151/2012 Of The European Parliament And Of The Council of 21 November 2012 on quality schemes for agricultural products and foodstuffs. Official Journal of the European Union L 343 of 14/12/2012

Ola BAREJA-WAWRYSZUK (PhD) is the Doctor of Sciences (Economics and Finance) at Siedlce University of Natural Sciences and Humanities, Institute of Management and Quality Sciences, Institutional Coordinator of International Cooperation.

Research interest: local food systems, short distribution channels, rural growth, supply chains, logistics.

ORCID ID: 0000-0002-3791-5736

Make your research more visible, join the Twitter account of ENTREPRENEURSHIP AND SUSTAINABILITY ISSUES:

@Entrepr69728810

Copyright (C) 2020 by author(s) and VsI Entrepreneurship and Sustainability Center

This work is licensed under the Creative Commons Attribution International License (CC BY).

http://creativecommons.org/licenses/by/4.0/

(c) (i) Open Access 